\title{
The syntactic analysis of the Dutch absentive construction ${ }^{*}$ Hans Broekhuis
}

\begin{abstract}
This squib discusses Dutch absentive constructions like Jan is vissen 'Jan is off fishing'. The literature on this construction so far has mainly paid attention to the meaning of the construction. This paper focuses on the syntactic analysis; two competing approaches will be compared according to which the verb zijn is, respectively, a copular verb and an auxiliary verb. It will be shown that the latter approach is the correct one.
\end{abstract}

\section{Introduction}

When zijn is used as an auxiliary verb, it normally functions as a perfect or passive auxiliary, but there is also a more restricted use of zijn illustrated in (1) in which it selects a bare infinitive. De Groot (2000) has called this construction the absentive given that it expresses that the referent of the subject of the clause is "absent" in a sense to be made precise in Section 2; I will follow De Groot by rendering this semantic aspect by means of the particle off in the English translations. Haslinger (2007: ch.2) argued that example (1) is a case of a regular copular construction, that is, the string is vissen is analyzed as consisting of the copular zijn followed by a predicate in the form of a nominal infinitive. I will argue, however, that we are dealing with a verbal complex is vissen, that is, zijn functions as an auxiliary verb and is followed by an infinitival main verb.

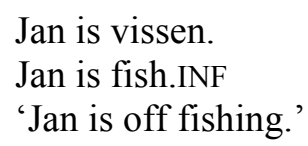

The discussion is organized as follows. Section 2 will provide a review of a number of semantic aspects of the absentive construction, which is mainly based on De Groot (2000) and Haslinger (2007: ch.2) in order to give the reader a feel for the construction involved. Section 3 constitutes the core part of this squib and will review the available evidence in favor of the two syntactic analyses sketched above. I will show that the auxiliary verb analysis is better equipped to handle the relevant data than the copular construction analysis.

\section{Meaning}

The absentive construction exhibits certain semantic similarities with clauses containing the aspectual verbs gaan 'to go' and komen 'to come' in (2). These verbs may be purely aspectual but may also be used such that the lexical meaning of the corresponding main verbs gaan and komen remains active; in that case, aspectual gaan and komen express not only inchoative aspect but also that the referent of the subject of the clause undergoes some change of location with respect to the deictic center, which is normally contextually determined or, by default, taken as the "here and now" of the speaker and/or the addressee. Under the default interpretation, the examples in (2) express that Jan will leave/join the speaker/addressee in order to perform the activity of fishing; the adverbs marked with a dollar sign require that the context provide additional information.

\footnotetext{
* I like to thank the external reviewer and the editors for their comments, which enabled me to clarify the discussion at various places.

${ }^{1}$ Since the notion of deictic center is not relevant for the central issue of this article, I refer to De Groot (2000) and Haslinger (2007:ch.2) for a more detail discussion.
} 
(2) a. Jan gaat daar $/ \$$ hier vissen.

Jan goes there/here fish.INF

'Jan is going there in order to fish.'

b. Jan komt hier/ ${ }^{\$}$ daar een tijdje vissen.

Jan comes here/there a time fish.INF

'Jan will come here in order to fish.'

The absentive construction is like the aspectual construction with gaan in that it expresses that the subject of the clause is not at the implied deictic center; under its default interpretation, example (3a) expresses that Jan is not in the vicinity of, and, in fact, out of reach of the speaker/addressee. ${ }^{2}$ Furthermore, the construction expresses that Jan is engaged in the activity of fishing in a broad sense. The addition in a broad sense is needed to account for the aspectual difference between the absentive and the progressive aan het + infinitive constructions like (3b).

(3) a. Jan is vissen.

Jan is fish.INF

[absentive]

'Jan is off fishing.'

b. Jan is aan het vissen. [progressive aan het + infinitive construction]

Jan is AAN HET fish.INF

'Jan is fishing.'

Whereas (3b) necessarily implies that the eventuality of Jan fishing includes the moment of speech, example (3a) need not imply this; it covers a larger range of activities including the leaving of the deictic center, the travelling to the place where the activity denoted by the bare infinitive takes place, the performance of the activity itself, and the return to the deictic center-as long as Jan is engaged with one of these activities, sentence (3a) will be considered true. That this is the case is clear from the fact that the speaker may actually start to use (3a) at the moment that Jan has left the house (and is thus out of the speaker's reach). In fact, examples like (4) are very frequent when the speaker wants to announce that he is leaving in order to do something (and will thus be out of the addressee's reach).

(4) a. Ik ben vissen!

I am fish.INF

'I am off fishing.'

The absentive is thus typically used when (i) the subject of the clause has left the deictic center, (ii) is out of reach of the speaker/addressee, and (iii) is involved in a broad sense in the activity denoted by the bare infinitive. De Groot further claims that the absentive implies that the subject will return to the deictic center after a certain period of time, which is predictable on the basis of pragmatic knowledge or former experience. This is, however, contested by Haslinger (2007: ch.2), who provides the idiomatic expression in (5a) as a counterexample to this claim. Given the idiomatic nature of the expression, it is not immediately clear how strong this argument is, so I will leave this issue open. Haslinger seems correct, however, in claiming that the time span during which the subject will be out of reach need not be predictable; examples like (5) are completely natural.

\footnotetext{
${ }^{2}$ The notion out of reach is essentially pragmatically determined. It often involves physical distance but may also include other factors. For example, it is not normal to say Marie is werken 'Marie is off working' when Marie is in a room adjacent the one where the speaker is located, but it is possible to say Marie is douchen 'Marie is off showering' when the speaker is in a room adjacent to the bathroom. Conventions concerning privacy make Marie sufficiently out of reach in the latter case to justify the use of the absentive.
} 
(5) a. Jan is hemelen.

Jan is be.in.heaven

'Jan has died.'

b. Jan is fietsen en ik heb geen idee wanneer hij terug is.

Jan is cycle.INF and I have no idea when he back is

'Jan is off cycling and I have no idea when he will be back.'

Although De Groot may somewhat overstate the relevance of pragmatic knowledge, he is certainly right in emphasizing the relevance of the speaker/hearer's knowledge of the world in that the projection of the bare infinitives typically denotes eventualities that have a typical setting or that are typical for the referent of the subject of the clause. When we take the deictic center to include Marie's home, her husband may use example (6a) to refer a series of events starting with Marie leaving the house, getting into her car, driving to the post office, dropping the letter into the letterbox, and returning home. And the use of an example like (6b) would be strange when Marie is not a regular soccer player.

(6) a. Marie is even een brief posten.

Marie is for.a.moment a letter post.INF

'Marie is off for a moment posting a letter.'

b. Marie is voetballen.

Marie is play.soccer.INF

'Marie is off playing soccer.'

De Groot (2000) and Haslinger (2007) further show that there are a number of semantic restrictions on the phrase headed by the bare infinitive. ${ }^{3}$ The most important ones are that the subject of the clause is agentive and that the eventuality expressed by this phrase has a certain duration. The bare infinitive is therefore generally an (in)transitive verb denoting an activity, as in (7a), or an accomplishment, as in (7b).

(7) a. Jan is wandelen.

Jan is walk.INF

'Jan is off walking

b. Jan is een boterham eten.

Jan is a sandwich eat.INF

'Jan is off eating a sandwich.'

The agentivity restriction is also clear from the fact illustrated by example (8a) that unaccusative verbs do not seem to be possible. ${ }^{4}$ This also accounts for De Groot's observation (for which he provides a semantic account) that examples like (7a) become infelicitous when we add a directional predicate given that this makes the movement verb unaccusative, as is clear from auxiliary selection in the perfect tense; see the contrast between Jan heeft/*is gewandeld 'Jan has walked' and Jan is/*heeft naar Groningen gewandeld 'Jan has walked to Groningen'.

\footnotetext{
${ }^{3}$ The nature of these semantic restrictions are sometimes somewhat obscure, as is clear from the fact that De Groot and Haslinger occasionally have different acceptability judgments.

${ }^{4}$ Unaccusative verbs never take an accusative object, and their subjects stand in a similar semantic relation with the unaccusative verb as the direct objects with a transitive verb and are thus non-agentive. Dutch unaccusative verbs can often be recognized by the fact that they select the auxiliary zijn 'to be' in the perfect tense. See Broekhuis (1997) for a review of the literature on this verb class.
} 
(8) a. *Jan is vertrekken/vallen/stijgen/emigreren.

Jan is leave.INF/fall.INF/rise.INF/emigrate.INF

b. ${ }^{* ?}$ Jan is naar Groningen wandelen.

Jan is to Groningen walk.INF

'Jan is off walking to Groningen.

Another restriction on the use of the absentive is that the eventuality denoted by the bare infinitive is seen as a discrete unit that is performed in an uninterrupted fashion. This is clear from the fact that when the infinitive denotes an accomplishment, the referent of the subject is only expected to return to the deictic center after he has completed the eventuality. The two examples in (9), for example, have different implications for the time span that Marie will be absent; while this time span may be short in the case of (9a), example (9b) strongly suggests that Marie is spending a sabbatical in some far-off place. ${ }^{5}$

(9) a. Marie is een brief schrijven.

Marie is a letter write.INF

'Marie is off writing a letter.'

b. Marie is een boek schrijven.

Marie is a book write.INF

'Marie is off writing a book.'

The meaning of the absentive is non-compositional in the sense that it expresses the subject's absence without there being overt material available that could be held responsible for that semantic aspect. That this semantic aspect is really present is shown again by the question-answer pairs in (10) that show that the sentence Hij is vissen 'He is off fishing' cannot only be used to answer to a question like Wat is Jan aan het doen? 'What is Jan doing?' but also to a question like Waar is Jan? 'Where is Jan?'.

(10) a. Wat is Jan aan het doen? Hij is vissen.

what is Jan AAN HET do he is fish.INF

'What is Jan doing? He is off fishing.'

b. Waar is Jan? Hij is vissen.

where is Jan he is fish.INF

'Where is Jan? He is off fishing.'

The acceptability of the question answer-pair in (10b) may simply be due to the fact that the use of the absentive involves extensive knowledge of the subject's routine, more specifically, that he is normally not performing this activity of fishing at the deictic center. ${ }^{6}$ Haslinger (2007:ch.2) claims, however, that this semantic aspect is syntactically encoded and her study can be seen as an attempt to formally capture this notion by extending traditional Control Theory. I will not discuss this attempt here given that it is crucially based on the copular construction analyses that I will argue against in the following section.

\section{Is the bare infinitive nominal or verbal in nature?}

This section discusses two competing syntactic approaches of the absentive construction. According to the first approach, represented in (11a), the verb zijn functions as a copular verb

\footnotetext{
${ }^{5}$ Some speakers may find it difficult to imagine a suitable context for examples like (9) given that they also imply that Marie is a professional or at least a habitual writer of letters/books.

${ }^{6}$ Ronny Boogaart correctly points out that the question in (10b) can also be answered by means of the progressive construction Hij is aan het vissen 'He is fishing', provided that the speaker and addressee know that Jan has a fixed fishing location. The crucial thing is that the absentive can also be used when this knowledge is lacking.
} 
and is thus combined with a nominalization functioning as a predicate. According to the second approach, the verb zijn functions as an auxiliary verb and is combined with the projection VP of an infinitival main verb, as in (11b).

(11) a. Jan is copular $_{\mathrm{NP}}$ een boek kopen]].

Jan is a book buy.INF

[copular construction analysis]

'Jan is off buying a book.'

b. Jan is auxiliary $_{\text {[vp }}$ een boek kopen]]

Jan is a book buy.INF

[auxiliary verb analysis]

'Jan is off buying a book.'

Semantic considerations seem to favor the analysis in $(11 \mathrm{~b})$, given that BARE-INF nominalizations like een boek kopen 'buying a book' normally do not denote properties that can be attributed to the referent of the subject of a copular construction. ${ }^{7}$ This section will show that although the syntactic tests that can be used to select one of the two options do not always provide straightforward results, the auxiliary verb analysis in (11b) seems to be the superior one.

The two analyses in (11) make different predictions when it comes to word order; if we are dealing with a copular construction, the presumed nominalization functions as the predicate and is therefore expected to precede the copular verb in clause-final position; if we are dealing with a construction in which zijn functions as an auxiliary verb, the bare infinitive must be a main verb and is therefore expected to be able to follow zijn in clause-final position. Haslinger (2007:ch.2) claims that the infinitive must precede the verb zijn and, thus, that the copular construction analysis is the correct one.

(12) a. dat Jan $<$ vissen $>$ is $<\%$ vissen $>$.

that Jan fish.INF is

'that Jan is off fishing.'

b. dat Jan <een boek kopen> is $<*$ een boek kopen>.

that Jan a book buy.INF is

'that Jan is off buying a book'.

It is indeed the case that many of my informants prefer the order vissen is in (12a), but the alternative order is vissen is also accepted by at least some of these informants (including myself), for which reason I marked this order by means of a percentage sign. I also found the order zijn-infinitive on the internet for, e.g., the intransitive verbs fietsen 'to cycle', logeren 'to stay', sporten 'to do sport', wandelen 'to walk', werken 'to work', and winkelen 'to shop'. Haslinger notes the same thing in footnote 48 on page 63 but nevertheless claims the order $z i j n$-infinitive to be ungrammatical, because speakers that accept this order in examples like (12a) reject it when the infinitival phrase is more extensive, as illustrated in (12b) above. She fails to note, however, that the relevant order much improves if the infinitive and its object are separated by the verb zijn, as shown in (13a). Examples (13b\&c) illustrate the same by means of examples that were taken from the internet: a Google search on the strings [boodschappen is doen] and [de hond is uitlaten] performed at January 7, 2013, resulted in, respectively, 56 and 31 hits, most of which instantiate the absentive construction. ${ }^{8}$

${ }^{7}$ It must be noted that Haslinger (2007:41) explicitly claims (but without much discussion) that phrases like een boek kopen do denote properties in absentive constructions.

${ }^{8}$ Embedded absentive constructions do not seem to be very frequent and are often difficult to find because the intervention of other construction types (e.g. infinitival nominalizations in subject position followed by a finite verb in second position), which makes it hard to compare the relative frequencies of the two word orders. I am therefore not able at this moment to say what the relative frequency of the object-zijn-infinitive and the object-infinitive-zijn order is. 
(13) a. dat Jan een boek $<$ kopen $>$ is $<\%$ kopen $>$.

that Jan a book buy.INF is

'that Jan is off buying a book'.

b. dat hij boodschappen is doen.

that he purchases is do.INF

'that he is off doing his shopping'

c. dat hij de hond is uitlaten.

that he the dog is out-let.INF

'that he is off walking the dog'.

Even if we interpret the fact that many speakers prefer the order infinitive-zijn in examples like (12) as evidence in favor of the copular construction analysis, we cannot straightforwardly adopt it given that it wrongly predicts that the infinitive would also have to precede the clause-final verbal sequences in the corresponding perfect tense constructions, as in (14).

(14) a. ?'dat Jan vissen is geweest. that Jan fish.INF is been

b. ${ }^{*}$ dat Jan een boek kopen is geweest. that Jan a book buy.INF is been

Examples like (14) are dubious, the normal perfect tense forms being the ones given in (15); whereas the string is wezen vissen is very frequent, I found only one case on the internet with the string [vissen is geweest] that allowed an interpretation as an absentive construction. ${ }^{9}$ The fact that the bare infinitives from absentive constructions normally follow the other verbs in clause-final position strongly militates against analyzing them as nominal predicates.

(15) a. dat Jan is wezen vissen.

that Jan is be fish.INF

'that has been off fishing.'

b. dat Jan een boek is wezen kopen.

that Jan a book is be buy.INF

'that Jan has been off buying a book.'

The contrast in acceptability between (14) and (15) thus favors the auxiliary verb analysis of the absentive construction. This analysis is further supported by the fact that these examples exhibit the IPP-effect: wezen has the form of an infinitive and the examples in (16) show that they cannot be replaced by the participle form geweest 'been'. The obligatoriness of the IPPeffect in (15) and (16) indicates that the infinitive is verbal in nature, and, consequently, that the verb zijn cannot be analyzed as a copular verb.

(16) a. *dat Jan is geweest vissen.

that Jan is been fish.INF

b. *dat Jan een boek is geweest kopen.

that Jan a book is been buy.INF

A potential problem for the auxiliary verb analysis is that Haslinger claims that the sequence wezen + infinitive in (15) may also precede the verb zijn, as shown in (17). This may open the possibility again to analyze the italicized parts as nominalizations with the function of predicate of a copular construction.

\footnotetext{
${ }^{9}$ All other cases involved the progressive forms like dat Jan aan het vissen is geweest 'Jan has been fishing' or forms with the particle uit like dat Jan uit vissen is geweest, which will be briefly discussed later.
} 
(17) a. dat Jan wezen vissen is.

that Jan be fish.INF is

'that has been off fishing.'

b. dat Jan een boek wezen kopen is.

that Jan a book be buy.INF is

'that Jan has been off buying a book.'

However, a Google search performed on September 26, 2012, revealed that the constructions in (17) actually do not occur; the (a)-examples in (18) show that whereas the order is wezen vissen in (15a) occurs more than 100 times, the order wezen vissen is was not found (none of the hits for this search string instantiated the relevant word order). The (b)-examples show that I found similar results for the transitive string boodschappen is wezen doen. This shows that the orders in (17) are not the ones normally found in Standard Dutch.

(18) a. Clause-final is wezen vissen

$\mathrm{a}^{\prime}$. Clause-final wezen vissen is

b. Clause-final boodschappen is wezen doen

$\mathrm{b}^{\prime}$. Clause-final boodschappen wezen doen is

The discussion above strongly suggests that in constructions with more than two verbs the infinitive must always be final in the clause-final verbal sequence, and thus be separated from its objects (if present). This again militates against the copular construction analysis: under this analysis the infinitive heads a nominalization, and such nominalizations normally are impenetrable by external elements (like the clause-final verbs). Furthermore, example (19b) shows that nominalizations are normally islands for extraction.

(19) a. Jan verafschuwt [DP boeken kopen].

Jan loathes books buy.INF

'Jan loathes buying books.'

b. *Wat verafschuwt Jan [DP $t_{\mathrm{i}}$ kopen]?

what loathes Jan buy.INF

Haslinger claims, however, that the object of a transitive verb can be wh-moved; her examples are given in (20). If correct, this would again show that the copular construction analysis cannot be correct. ${ }^{10}$

(20) a. De poes is [muizen vangen].

the cat is mice catch.INF

'The cat is off catching mice.'

b. ${ }^{\%} \mathrm{Wat}_{\mathrm{i}}$ is de poes $\left[t_{\mathrm{i}}\right.$ vangen $]$ ?

what is the cat catch.INF

I will conclude this section by briefly comparing absentive constructions like Jan is vissen 'Jan is off fishing' with constructions like (21a), in which the absentive meaning is overtly expressed by means of the particle uit 'out'. We start by showing that the uit vissen zijn construction is a more special form of the run-of-the-mill copular construction in (21b) in which the particle out appears in isolation.

\footnotetext{
${ }^{10}$ This argument against Haslinger's analysis is somewhat less compelling given that some speakers (including myself) feel very uncomfortable with examples of this sort, for which reason I also added a percentage sign to the (20b).
} 
(21) a. Jan is een dagje uit vissen.

Jan is a day out fish.INF

'Jan is out fishing for a day.'

b. Jan is een dagje uit.

Jan is a day out

'Jan is out for a day (i.e. involved in some outdoor recreative activity).'

The claim that the sequence uit vissen in (21a) performs the same function as the particle uit in (21b) implies that it behaves as a constituent. That this is indeed the case is clear from the fact illustrated in (22a) that it may occur in sentence-initial position. Example (22b) further shows that the sequence cannot be interrupted by the verb in clause-final position; this also supports our proposal by showing that the infinitive cannot be construed as part of the verbal complex.

(22) a. Uit vissen is hij nog niet geweest.

out fish.INF is he not yet been

'He has not been out fishing yet.'

b. *dat Jan uit is vissen.

that Jan out is fish.INF

The word order of the phrase uit vissen is furthermore fixed: the infinitive vissen cannot precede the particle uit or be separated from it by means of $w$ h-movement: cf. *Jan is vissen uit and *Wat is Jan uit? '*What is Jan out?'.

The above suggests that the bare infinitive functions as a modifier of the adposition uit, which may also accounts for the fact that the infinitives in the uit vissen zijn construction normally denote recreational activities; typical examples are uit eten zijn 'to be out lunching/dining', uit jagen zijn 'to be out hunting', uit dansen zijn 'to be out dancing' and uit winkelen zijn 'to be out shopping', although there are also cases like uit werken zijn 'to be out working' and somewhat obsolete expressions like uit wassen gaan 'to go out cooking/washing' for performing domestic duties at other people's homes. Thus, example (21a) differs from (21b) in that the infinitive vissen simply specifies the outdoor activity that Jan is involved in.

The claim that the phrase uit vissen syntactically behaves as the predicate of a copular construction can be supported by the fact illustrated by the primed examples in (23) that it must always precede the verbs in clause-final position and does not trigger the IPP-effect; the absentive constructions in the primeless examples were discussed earlier and added here for comparison.

(23) a. dat Jan $<$ vissen $>$ is $<{ }^{\%}$ vissen $>$.

that Jan fish.INF is

'that Jan is off fishing.'

$\mathrm{a}^{\prime}$. dat Jan uit $<$ vissen $>$ is $<^{*}$ vissen $>$

that Jan out fish.INF is

'that Jan is out fishing.'

b. dat Jan is wezen/*geweest vissen.

that Jan is be/been fish.INF

'that Jan has been off fishing.'

$\mathrm{b}^{\prime}$. dat Jan uit vissen is geweest/*wezen

that Jan out fish.INF is been/be

'that Jan has gone out fishing.'

The contrasts between the primeless and primed examples in (23) are important because they highlight the fact that the absentive does not exhibit the behavior that we might expect from a 
copular construction, and thus enforce the conclusion from the previous subsection that the absentive construction is not a copular construction.

\section{Conclusion}

The discussion in Section 3 has shown that the copular construction analysis can be supported by the fact that many speakers prefer the order infinitive-zijn in non-perfect examples like (12). The analysis runs into problems, however, when we consider perfect tense constructions: the copular construction analysis predicts that the bare infinitive should again precede $z i j n$, but the reversed order seems to be the one that is actually preferred; it further implies that the infinitive functions as the head of a nominalization and thus wrongly predicts that the infinitive cannot be split from its object. The auxiliary verb analysis, on the other hand, does predict these facts. Although it does not really explain that many speakers prefer the order infinitive-zijn, it is compatible with this fact given that the order infinitive- $-\mathrm{V}_{\text {finite }}$ is found in many clause-final verb clusters consisting of two verbs. For this reason, it seems that we may conclude that this analysis is superior to the copular construction analysis and therefore deserves to be further developed by future research.

\section{Bibliography}

Broekhuis, Hans (1997). Twee typen subject. Nederlandse taalkunde 2:35-51.

De Groot, Casper (2000). The absentive. In Tense and Aspect in the languages of Europe, ed. Östen Dahl, 693-719. Berlin/New York: Mouton de Gruyter.

Haslinger, Irene (2007). The syntactic location of events. Aspects of verbal complementation in Dutch, University of Tilburg: PhD thesis. 